\title{
The Effects of Corporate Governance Attributes on Credit Ratings and Bond Yields
}

\author{
Michael Bradley ${ }^{1}$, Dong Chen $^{2}$, George Dallas ${ }^{3}$ and Elizabeth Snyderwine ${ }^{4,5}$
}

\begin{abstract}
This study examines the empirical relations between the governance structure of public corporations in the United States and the credit ratings and pricing of their debt securities. We study an unbalanced panel of 775 unique firms from 2001 through 2007. Consistent with the existing literature, we find that the primary determinant of a firm's credit rating is its financial condition. However, governance attributes relating to transparency, ownership structure, shareholder rights, board structure and executive compensation are significantly related to credit ratings as well, even after accounting for the financial condition of the firm. We also find that the presence of anti-takeover measures is associated with higher credit scores for firms with investment grade debt and lower for firms with speculative grade debt. Finally, our empirical results suggest that stable boards, defined as boards having attributes relating to tenure, liability indemnification and classified board structures, have higher credit ratings and lower bond spreads. We conjecture that boards with greater stability may be better positioned to take into consideration the longer term interests of the firm as a whole, thereby benefiting the firm's bondholders.
\end{abstract}

September 25, 2008

(Third Draft - Comments Welcome)

Keywords: corporate governance, credit risk, credit rating, bond spreads

\footnotetext{
${ }^{1}$ Duke University

${ }^{2}$ University of Baltimore

${ }^{3}$ F\&C Management Ltd.

${ }^{4}$ Independent Consultant and adjunct professor (Loyola University Chicago and the University of Notre Dame).

5 The authors would like to thank the Duke Global Capital Markets Center for financial support and Standard \& Poor's and The Corporate Library both for providing data to this project, as well as for their input into the discussions surrounding our research methods. In particular we would like to recognize Cliff Griep, Laurence Hazell and Dan Konigsburg at Standard \& Poor's and Annalisa Barrett and Ric Marshall at The Corporate Library for their support and helpful insights.
} 


\section{Introduction and Summary}

This study examines the empirical relation between the governance structure of public corporations in the United States and the credit rating and pricing of their debt securities. We study an unbalanced panel of 775 U.S. firms from 2001 through 2007 for credit ratings, and 7,456 bond-year observations from 2002 through 2007 for bond spreads. ${ }^{6}$ Our analysis proceeds in two steps. First we examine the extent to which a firm's various governance metrics or characteristics are related to the credit rating assigned by Standard \& Poor's (“S\&P”) to the firm's long-term unsecured debt, controlling for the firm's financial condition and industrial sector. ${ }^{7}$ We then test whether the governance metrics are related to the yields on corporate debt, given the firm's financial condition and credit rating. Our purpose is to examine the extent to which bond yields reflect governance factors that are not explained by the firm's financial condition or its credit rating.

Our empirical results can be summarized as follows. We find that the primary determinants of a firm's credit rating are its financial condition and a measure of its earnings' quality. We also find that governance attributes relating to ownership structure, shareholder rights, board structure and executive compensation may "explain" differences in credit ratings that are not explained by the financial condition of the firm. A key finding in this regard is that holding a firm's financial condition and industrial sector constant, the relation between its credit rating and the presence of anti-takeover mechanisms differs depending on whether the firm's credit rating is of investment or speculative grade. Specifically, we find a negative relation between anti-takeover mechanisms and credit ratings for firms with below investment grade debt and a positive relation between anti-takeover mechanisms and credit ratings for firms with investment grade debt. In other words the more anti-takeover mechanisms (and implied management entrenchment), the worse the credit rating for below investment grade bonds. Conversely, we find a positive relation between anti-takeover mechanisms and ratings for firms with investment grade debt. One possible explanation for these results is that the ratings reflect the fact that investment grade debt may lose

\footnotetext{
${ }^{6}$ S\&P assigns credit ratings to individual corporate bond issues, taking into consideration the individual firm's credit quality and the specific terms and conditions of each bond issue. If bonds are issued by the same firm and have the same terms, conditions and seniority, the bonds will have the same credit rating. For purposes of this study we are using the senior unsecured debt rating of the companies as provided by S\&P

${ }^{7}$ This study focuses exclusively on credit ratings assigned by S\&P as an indicator of credit risk. S\&P's corporate credit ratings have been tested over time in various studies (see References), and have a demonstrated track record with regard to assessing credit risk and the potential for corporate debt default.
} 
value if the firm is taken over in a highly leveraged transaction or by a firm with weaker credit. Clearly, anti-takeover mechanisms reduce this possibility. On the other hand, holders of speculative grade debt could benefit from a takeover if an acquiring firm was in a better financial condition or if the combination would generate synergistic gains to the creditors of both firms from an operational perspective. ${ }^{8}$

Another important finding of our empirical analyses is a significant positive relation between credit ratings and what we regard as attributes of board stability. We find that ratings are higher for firms with a higher percentage of directors with 15 years of service on the board, firms with a higher percentage of directors who hold stock, firms with classified boards and firms whose charter, bylaws and compensation agreements provide for director liability and indemnification. This cluster of attributes suggests that boards with greater tenure, firm and sector knowledge, financial exposure, and protection from liability may be better positioned to take a long term perspective and have a greater ability to exercise discretion relative to executive management. In a fiduciary context, this suggests that more established directors and boards may be better equipped to act as longer term stewards for the firm as a whole including creditors and possibly other non-financial stakeholders, and not focus exclusively, or disproportionately, on the potentially short-term interests of shareholders. This finding is particularly interesting in that it challenges the conventional wisdom that long standing, indemnified and entrenched boards lose their objectivity over time to the influences of executive management. Indeed, our findings suggest the opposite might be the case, at least from a creditor's perspective.

For the most part, the results of our analysis of bond spreads mirror those of our analysis of credit ratings. ${ }^{9}$ Credit ratings are the primary determinants of spreads - the higher the rating, the lower is the spread between the yield on the bond and the yield on a U.S. Treasury bond with the closest time to maturity. Our results indicate that, by and large, governance variables that are positively related to ratings are negatively related to spreads. ${ }^{10}$ Importantly, this is the case with regard to the index of board stability that we develop which proves statistically significant both for credit ratings and for bond spreads. We also

\footnotetext{
${ }^{8}$ Thus, our results are more nuanced than those reported in two recent papers that have focused on credit ratings: Larcker, Richardson and Tuna (2004) and Ashbaugh-Skaife, Collins and LaFond (2006) (“ACL”). These authors report a positive relation between antitakeover provisions and credit ratings. The authors argue that strong anti-takeover provisions indicate relatively weak stockholders' rights, which translates into strong creditors' rights. Neither study however, analyzes speculative and investment grade debt separately. ${ }^{9}$ All of the financial variables except for firm size and subordinated debt have the opposite signs in the ratings and spread regressions.

${ }^{10}$ The notable exception is the percentage of directors who hold none of the firm's shares. This variable is negatively related to both credit ratings and credit spreads. This suggests that the market may interpret certain governance factors different from the implications reflected in credit ratings.
} 
find the relation between spreads (the risk premium) and anti-takeover mechanisms is positive and stronger for firms with speculative grade debt. Since our analyses of bond ratings and bond yields are based on different samples ${ }^{11}$, these results lend credibility to our methodologies and findings.

\section{Research Contribution}

The conclusions reached by this study have relevance both for practitioners and academics in better understanding how corporate governance impacts credit quality and the market's perception of credit risk. While there is an extensive and growing literature on the relation between governance attributes and security pricing, we believe that this study adds significantly to this burgeoning literature. Specifically, our study is distinguished from earlier research in terms of scope, methodology, and time horizon.

Our results are based on multiple years of data ${ }^{12}$, as opposed to other studies which typically provide only a one-year snapshot. A major benefit of our longer timeframe is that we are able to show that a number of results that have been reported in the literature are only relevant over a very short time period.

We employ additional governance variables in our analysis to test for relations with credit ratings and bond yields. We examine the yields of seasoned bonds that are trading in the market rather than the yields of newly issued bonds. Analyzing the prices of seasoned bonds avoids potential distortions due to the uncertainties and transaction costs associated with a new issue, and this arguably presents a more refined view of the market's perception of risk as embodied in corporate bond yields.

To date, corporate governance research has focused primarily on measuring the link between good and bad governance and firm values. The most notable papers in the literature include Gompers, Ishii, and Metrick (GIM, 2003) and Bebchuk, Cohen and Ferrell (BCF, 2004). Both sets of authors show that valuation multiples during the 1990s are significantly related to corporate governance characteristics. The GIM Index (“GINDEX”) of twenty-four governance provisions, essentially created from IRRC’s database of listed firms' anti-takeover provisions in the 1990s, is a scoring system which rates firms as having either strong or weak shareholder rights. GIM show that firms with higher index values, i.e., weak shareholder

\footnotetext{
${ }^{11}$ The ratings regressions are based on the COMPUSTAT data base covering 2001 to 2007, while the spread regressions are based on a "snapshot" and the proprietary database from S\&P, which contains bond pricing information at end of March trading date for each year from 2002 to 2007.

${ }^{12}$ For the rating sample, the year range is from 2001 to 2007; for the spread sample, the year range is from 2002 to 2007.
} 
rights, which they interpret as an indication of poor governance, have lower valuation multiples. BCF test GIM's results and find that only six of the twenty-four governance provisions are material. Brown and Caylor (2004), using data from ISS, affirm BCF's results by showing that only a small subset of governance factors in the public domain are related to firm valuation.

Several recent papers have attempted to link corporate governance and credit or bond ratings. There is a divergence of views relating to the trade off between good and bad governance and what benefits shareholders and bondholders. Adopting aspects of a corporate governance framework developed by S\&P, ${ }^{13}$ Ashbaugh, Collins and LaFond (2006) (“ACL”) find that firms with higher values of the GINDEX have higher credit ratings. They also find that credit ratings are negatively associated with both the number of block holders who own at least 5\% and CEO power on the board, while credit ratings are positively related to: 1) the degree of financial transparency; 2) overall board independence, 3) board stock ownership and 4) board expertise. ACL show that moving from the lower quartile to the upper quartile of the GINDEX doubles a firm's chances of receiving an investment grade credit rating. In so doing they also suggest that weak governance can result in firms incurring higher debt financing costs.

Several other papers have attempted to show a link between governance factors, credit ratings, and bond yields. Bhoraj and Sengupta (2003) link corporate governance mechanisms to higher credit ratings and lower bond yields, showing that firms with greater institutional ownership and stronger outside control of the board enjoy lower bond yields and higher ratings on their new bond issues. In addition, they suggest that the governance mechanisms which they tested can reduce information asymmetry between firms and lenders. A recent paper by Billett, King and Mauer (2004) provides empirical evidence that takeovers can benefit bondholders because of a so-called co-insurance effect: the reduction of overall firm risk due to operational diversification of firm businesses after mergers. Klock, Mansi and Maxwell (2004) find that strong anti-takeover provisions are associated with a lower cost of debt financing while weak anti-takeover provisions are associated with a higher cost of debt financing. Larker, Richardson and Tuna (2004) conclude that firms with large boards and anti-takeover provisions tend to have better debt ratings and lower abnormal accruals, while Litov (2005) provides evidence that firms with weaker shareholder rights have higher credit ratings and lower bond yields. Cremers, Nair and Wei (2006) investigate the effects of

\footnotetext{
${ }^{13}$ See S\&P's corporate governance scoring criteria (in References). Note that these governance criteria have been applied separately and independently from S\&P's credit rating process.
} 
shareholder governance mechanisms and maintain that the impact of shareholder control on credit risk depends on takeover vulnerability. Shareholder control is associated with higher yields if the firm is exposed to takeovers.

To our knowledge, ours is the only study that examines the effects of a comprehensive set of governance factors on both bond ratings and bond yields. In contrast, much of the previous research examines either the relation between governance and only ratings or yields, presuming that yields or ratings would be determined accordingly, or the relation between only a small set of governance factors and ratings and spreads (Bhoraj and Sengupta (2003)). While ratings are primary determinants of bond yields, we find that the market implicitly "prices” other factors, including factors related to the firm's governance attributes.

\section{Data Selection, and Sources}

\section{A. Corporate Governance Variables and Data}

Of course the selection of independent variables capable of capturing the many facets of corporate governance is limited by data availability. We seek to select variables that allow us to assess the mechanism by which corporate governance factors affect credit quality or the perceptions of investors in the pricing of corporate debt. To this end, we build on and extend a framework developed by S\&P designed to measure and analyze corporate governance attributes dating back to the late 1990s. ${ }^{14}$ The framework is based on four main components or categories: (1) Ownership Structure and External Influences; (2) Shareholder Rights and Stakeholder Relations; (3) Transparency, Disclosure and Audit; and (4) Board Structure and Effectiveness. We complement the S\&P framework by adding three additional independent variables: (5) Executive Compensation; (6) Executive Turnover; and (7) whether the firm is incorporated in Delaware. ${ }^{15}$

\footnotetext{
${ }^{14}$ The S\&P framework was first developed in 1999, and was based on factors arising in statute, "soft law" or codes of conduct, listing requirements and a vast literature relating to governance practices. These criteria were drafted with an eye toward global application and were guided in part by the transnational corporate governance principles published by the OECD in the late 1990s. The focus was on assessing those factors that affect the relations between officers and directors on the one hand, and the firm's financial stakeholders (shareholders and creditors) on the other.

${ }^{15}$ Francis, Hasan, John, and Waisman (2006) provide evidence that firms incorporated in Delaware firms have higher costs of debt as reflected in higher bond yields. They argue that different state laws, especially state anti-takeover laws, affect the cost of capital. The fiduciary orientation of directors of Delaware is also more clearly framed in terms of shareholder interests, as opposed to the interests of the firm as a whole, which can include stakeholders such as creditors. We thus include a Delaware incorporation dummy as a separate governance variable.
} 
While our study employs and extends the general framework developed by S\&P, the governance variables we employ are not proprietary to S\&P. All data are available from either The Corporate Library (TCL) or Investor Responsibility Research Center (IRRC), who in turn obtain data from regulatory filings and disclosures including annual reports, 10Ks and proxy statements.

Tables 1 and 2 present definitions, type and the source of all of the data used in the study. Below we discuss the nature and relevance of each of the seven main categories of our analysis.

Ownership Structure. We capture the effects of ownership by examining the effects of insider ownership, institutional ownership and block shareholdings. These variables relate to differing degrees and forms of ownership. Ownership can be a critical dimension to overall corporate governance, particularly in cases where the interests of block holders may not be aligned with those of smaller financial stakeholders. While insider ownership may align the interests of a management and director team with that of shareholders, whether and to what extent this is beneficial to creditors is an empirical issue. In cases where ownership is widely dispersed, the governance risk is that no individual shareholder will be in a position to exert meaningful influence over the managers acting as the shareholders' agents. In such cases, institutional investors have the potential to play a more meaningful role in terms of influence and engagement than individual shareholders, which in principle is a positive feature. There are conflicting views and evidence as to whether specific forms of ownership are intrinsically positively or negatively related to a firm's financial performance. However, other credit related research (e.g., ACL) has suggested that the presence of block holders has a negative impact on credit ratings. For purposes of our study we believe it is important to test for ownership structure, if nothing else as a control variable.

Shareholder Rights and Stakeholder Relations. Our shareholder rights variables have been featured prominently in many corporate governance research studies. This is in part because they are readily measurable, and because they link directly to the ability of shareholders to influence the governance of the company they own through exercising rights established in the company's charter or bylaws. Both GIM and BCF provide some empirical support for the notion that anti-takeover measures lead to management entrenchment and decreased firm value. From a creditor perspective, however, the relevance of shareholder rights is less obvious, and possibly a source of conflict. 
As much of the literature argues, anti-takeover measures reduce the degree to which managers are monitored by agents in the market for corporate control, which leads to higher agency costs and lower equity values. Moreover, if the managers are sufficiently entrenched, they can unilaterally veto a takeover bid and preclude their stockholders from receiving a takeover premium. But for creditors, anti-takeover provisions have quite different implications. Takeovers or other related activity, especially those with highly leveraged financing, increase the risk of current creditors and hence impact their wealth negatively. But mergers by companies in different lines can also decrease the overall risk level of the combined company through diversification. This "co-insurance” effect can benefit creditors in specific cases. There is empirical evidence supporting both propositions. ${ }^{16}$

While GIM suggests that an index (the "GINDEX") composed of twenty-four major anti-takeover provisions as an anti-takeover measure, BCF argue that most of the components in the GINDEX do not exert meaningful anti-takeover forces. They find that a more refined entrenchment index (EINDEX), comprised of only six variables captures all the significance of GINDEX on firm valuation. ${ }^{17}$

Out of the twenty-four GINDEX components, we create a new index, termed BINDEX, by adding the indicator variables ( 0 or 1$)$ for the presence of director liability protection, director indemnification, and a classified or staggered board. We argue that this index proxies for the level of board stability and discretion. A higher value of this index indicates that the director team may be more conservative or better positioned to exercise greater discretion to focus on the longer term perspective of the firm. We use the tenure of the CEO as a separate measure of management stability (entrenchment).

The entrenchment of executive managers or directors may create incentive problems that negatively impact a firm's shareholders. However, whether entrenchment is also harmful to creditors is an open question. On the one hand, creditors are also disadvantaged by potential incentive problems that may decrease the company's performance. On the other hand, however, entrenchment could also represent a more stable management/director team and hence suggest more stable corporate policies/strategies.

\footnotetext{
${ }^{16}$ While ACL, Larcker, Richardson, and Tuna (2004), Klock, Mansi, and Maxwell (2005) suggest that anti-takeover measures are viewed positively by either credit rating agencies or bond traders, Billett, King, and Mauer (2004) find that bonds of target firms earn positive announcement period returns during mergers and acquisitions, especially those with ratings below investment grade, which is consistent with a "co-insurance" effect.

${ }^{17}$ See Table 2 for the components of EINDEX and GINDEX.
} 
Bertrand and Mullainathan (2003) provide evidence that entrenched management follow more conservative policies.

Transparency and Disclosure. High standards of transparency and clear and reliable disclosures are important to both shareholders and creditors, though in many cases credit rating agencies may benefit from direct access to corporate managers and information, and are therefore less constrained by what is publicly disclosed. A study by S\&P of U.S. listed companies concludes that disclosure does not differ notably from company to company, given the conformity to U.S. GAAP and SEC mandated disclosure standards. ${ }^{18}$ However, we have identified an important variable that relates to the issue of transparency.

Following recent developments in financial accounting, we entertain a variable that proxies for the quality of a firm's reported earnings. Ecker, Francis, Kim, Olsson and Schipper (2006) (“Ecker et al.”) argue that the quality of a firm's earnings is a priced factor in establishing capital market equilibrium. They calculate what they refer to as “E-loadings” which reflect the quality of a firm's earnings. This Eloading variable can be viewed as a governance variable that proxies for responsible financial stewardship. The measure is based on the standard deviation of the residuals of a time-series regression of the firm's total current accruals on past, present, and future values of the firm's cash flows from operations, the firm's most recent change in revenues and the level of the firm's property, plant and equipment for each of the preceding five years. ${ }^{19}$ The measure is further refined by calculating the degree of volatility that can be attributed to managerial intervention and the degree of volatility that can be attributed to the inherent nature of the firm's businesses.

The E-loadings are then obtained by entertaining a four-factor asset pricing model that includes the Fama-French three factors (market return premium, firm size, market-to-book) and the above measure of earnings quality as the fourth factor. The E-loadings are the coefficients on this factor. Note that this measure represents the inverse of the quality of firm's earnings. A high E-loading value implies a high variance in the accruals' regression and a low quality of (reported) earnings. In order to facilitate exposition and provide a more intuitive interpretation of the effects of this variable on credit scores, we multiply the Eloading for each observation by -1 and denote the resulting variable Earnings Quality (EQ). Thus, in this

\footnotetext{
${ }^{18}$ See, e.g., Patel and Dallas (2002),

19 The intuition is that if there is a meaningful and sustaining relation between a firm's reported earnings and its cash flows, then we can conclude that the reported earnings are of high quality. Alternatively, if there is no relation between reported earnings and cash flow, then we can conclude that the reported earnings are of low quality.
} 
reformulation, the higher EQ, the higher the quality of the firm's reported earnings and, presumably, the higher (better) the firm's credit rating.

Board Structure and Effectiveness. Board effectiveness is a key aspect of corporate governance. Both creditors and shareholders have mutual interest in a strong board to provide oversight of management for the protection of financial stakeholders. In our study, this category contains the greatest number of variables, in part reflecting the presumed importance of the board in overall corporate governance. It is also the case that a number of different aspects of board structure are directly measurable from data provided in proxy statements and other corporate disclosures. The percentage of independent directors is likely to be homogeneous across the sampled companies, given the influence of NYSE and NASDAQ listing rules implemented in 2002. Other less homogenous variables include board size, the percentage of long tenured (over 15 years) directors, the percentage of "mature" directors (over 70 years old), the percentage of directors who hold at least 4 other directorships, the percentage of directors who failed to attend at least $80 \%$ of all board meetings, and the percentage of directors who do not have any equity holding. Empirically, there is mixed evidence on the relation between certain governance attributes and shareholder and creditor welfare, which are typically linked to board effectiveness. These include areas such as the role of board independence as well as whether the chairman and CEO roles should be combined or separated. ${ }^{20}$

State of Incorporation. The debate regarding whether competition among states for incorporations creates a "race to the bottom" or a "race to the top" has been waged in the literature for the past three decades. Daines (2001) finds that Delaware incorporated firms are more highly valued than firms incorporated in other states. He attributes this higher value to the higher likelihood that Delaware firms will be the target of a takeover bid due to the lack of defensive tactics available to the managers of those firms. Subramanian (2004), however, challenges Daines' conclusion by noting that the "Delaware effect" is mostly driven by small firms. While the question of whether state incorporation has a differential effect on firm performance is unsettled, Francis, Hasan, John, and Waisman (2006) provide evidence that Delaware incorporated firms have a higher cost of debt as evidenced by higher bond spreads. In this paper we further test whether Delaware incorporation has differential effect on firms’ credit ratings and bond spreads.

\footnotetext{
${ }^{20}$ Our data indicating whether the positions of CEO and Chairman are held by the same individual are available only after 2003. Our analysis of this subset of our data indicates that whether the two positions are held by one individual or two has no effect on either bond ratings or yields.
} 
Executive Compensation and Turnover. Since excesses in executive compensation stand out as a fundamental governance issue, this category warrants examination on its own. On the surface, executive compensation is more of a concern for shareholders than creditors, particularly in situations where options granted to executive management are not accompanied by pre-emption rights to existing shareholders or in situations where there is a large dilution overhang. Also, from a creditor's perspective, for many companies in our sample the interest coverage ratio for a CEO with compensation of \$20 million will not differ materially from the interest coverage ratio for a CEO with compensation worth $\$ 2$ million. At a deeper level, however, abuses of executive compensation may signal weak board oversight that should be a concern both to creditors and shareholders. Consequently we include in this category a range of variables which may affect the quality of governance: CEO base salary and bonus as a percentage of total compensation; the percentage of the firm's shares held by the CEO; and the tenure of the CEO.

\section{B. Credit Variables and Data}

We use S\&P's credit ratings as a measure of the credit risk of individual companies. Note that the credit rating process is fundamentally an assessment of a company's financial strength (specifically its vulnerability to default) and the operational or business risk factors that may influence a company's financial position over time. A multitude of factors are taken into consideration in individual credit ratings at S\&P. This typically includes consideration of country risks, industry risks, competitive risks and financial risks relating to earnings, cash flows, liquidity and balance sheets. It also can include consideration of management and governance related factors that are viewed as material to a company's financial strength. These factors are assessed on a case by case basis by individual rating committees. It is important to note that in the S\&P credit rating process, there is no formulaic algorithm employed to "score" a company's corporate governance in a way that has a mechanical relationship to the final rating outcome. Hence it is not circular to test for the relations of specific governance variables to S\&P credit ratings.

Anti-takeover defenses warrant particular attention in this regard. At S\&P, shareholder rights are not an explicit component of the credit rating criteria and are not systematically assessed as part of the credit rating process. As discussed previously, takeovers, particularly highly leveraged takeovers, can have the effect of destabilizing a company in a way that can impact creditors more than shareholders; it is also 
the case that in other situations takeovers can be positive from a credit perspective. This can be the case when a takeover results in a stronger, more business profile and/or a stronger consolidated financial position. Ex ante, it is not possible to fully anticipate the magnitude or direction of a takeover event on a company’s credit quality.

The ratings used in this project are S\&P's long term issuer credit ratings as reported in COMPUSTAT, a product of S\&P. Following ACL, S\&P credit ratings are grouped into seven categories (see Table 1 for the details of the grouping). Coding the dependent variable in this fashion assumes that the groupings are on a linear basis. Actual default and yield experience, however, suggests that these relationships are in fact non-linear, particularly in the differences between the A to BBB categories and the BBB to BB categories (the latter distinction separating “investment grade” from “speculative grade” risk). The non-linearity in credit scores requires us to employ ordered-logit regressions in the empirical tests.

\section{Bond Market Variables and Data}

Our bond market yields are taken from a proprietary database of S\&P that contains the prices of all rated corporate bonds at a particular point in time. We chose to sample firms after the first quarter of each year to best match in time the firms' disclosures relating to its financial statements and corporate governance structure. Specifically, we sample bond prices as of the end of the trading day in March for the years 2002-2007 21 . The sample includes only senior unsecured corporate debt. Based on the S\&P data we compute each bond's yield-to-maturity (YTM) and calculate the bond's spread by subtracting the YTM of a U.S. Treasury bond with the closest maturity date.

\section{Accounting/Financial Variables and Data}

All credit ratings and financial ratios are taken from COMPUSTAT and are defined by Data Item(s) in Table 1.

\footnotetext{
${ }^{21}$ We do not have the bond yield data for 2001. This gives one slight difference between the year coverage of our ratings sample and spread sample, as our ratings sample cover the year between 2001 and 2007.
} 


\section{Empirical Evidence}

\section{A. Financial Condition, Governance Attributes and Credit Ratings}

Our sample consists of an unbalanced panel of publicly traded corporations covering 2001 to 2007. After merging data from COMPUSTAT, CRSP, The Corporate Library (TCL), the Investor Responsibility Research Center (IRRC) and Thompson Financial (TF), we are left with roughly 500 firms in each year or 3,209 firm years representing 775 unique firms. (See Tables 1 and 2 for definitions and sources of the data used in this study.)

Table 3 presents our main results regarding the extent to which corporate credit ratings reflect a firm's financial condition on the one hand and its governance structure on the other. We begin with a model of credit ratings based on a firm's financial data which was developed by ACL.

Following ACL, we perform a series of ordered-logit regressions in which the dependent variable is a seven-categorical grouping of the credit ratings assigned by S\&P, with the highest rating corresponding to the highest ordinal value. ${ }^{22}$ Reported in Table 3 are the estimates of the coefficients of five ordered-logit regressions. A positive coefficient indicates that higher values of the independent variable lead to higher (better) ratings for the firms' senior unsecured long-term debt. ${ }^{23}$ All of the regression models reported in this study include year and Fama-French 48-industry fixed effects. In addition all standard errors are "clustered" at the firm level. ${ }^{24}$

The independent variables in these regressions are broadly divided into seven categories:

(1) Financial Data; (2) Earnings Quality ${ }^{25}$; (3) Ownership Structure; (4) Executive Compensation and Tenure; (5) Board Structure; and (6) Governance Indexes (7) Delaware Incorporation. Model 1 in Table 3 reports the relations between a firm's credit rating, its financial condition and its GINDEX. Model 2 in the

${ }^{22}$ See Table 1 for the specific groupings of credit ratings.

${ }^{23}$ The rating assigned by S\&P to a firm reflects its assessment of the risk (probability) that the firm will default on its senior, unsecured, long-term debt.

${ }^{24}$ It is critical to cluster the standard errors by firm, since most of our independent variables are persistent through time. Failure to cluster the standard errors leads to an underestimate of the standard errors of the estimates and an overestimate of the t-statistics. See Petersen (2007). Since much of the literature ignores the effects of clustered standard errors, a number of results reported in this paper are inconsistent with much of the existing literature. We believe that some of these inconsistencies may be due to the authors not clustering standard errors by firm. As noted elsewhere in another context, we can replicate the literature if we ignore clustering and other appropriate econometric issues.

${ }^{25}$ Since our measure of earnings quality is based on accounting data as well as the extent of earnings management in the firm, it is not clear whether we should include it with the financial data or governance data. We therefore chose to report it separately, particularly since it is such a significant explanatory variable. However, to the extent it can be viewed as a proxy for responsible financial stewardship it appropriately can be regarded as a governance variable. 
table reports the relations between our governance variables, earnings quality, GINDEX and credit ratings without regard to the firm's basic financial data. Model 3 includes both financial and governance variables.

The results of Model 1 show that the coefficients on all of the financial variables have the expected signs and all are statistically different from zero. Thus, credit ratings are higher (1) the larger the firm's market capitalization; (2) the lower the firm's leverage ratio; (3) the higher the firm's return on assets; (4) if the firm has not realized negative earnings over the past two years; (5) if the firm has no subordinated debt outstanding; (6) the higher the firm's interest coverage; and (7) the more capital intensive the firm's production function. These relations are highly significant, robust to almost all specifications of the statistical model and are consistent with the findings reported by ACL.

Interestingly, Model 1 shows no significant relation between ratings and the GINDEX. Recall that the GINDEX is purported to measure the degree of shareholder power relative to the power of the firm's management. ${ }^{26}$ A high GINDEX indicates that the firm has extensive anti-takeover devices in place and is therefore under the control of its management. GIM call these firms "dictatorships", emphasizing the relative power of management versus stockholders. On the other hand, a low GINDEX indicates that the firm has relatively few anti-takeover devices in place, which increases the power of stockholders and decreases the power of the firm's officers and directors.

Our finding that GINDEX is unrelated to credit scores is inconsistent with the findings reported by ACL. We should note that we can replicate the ACL results, including their results regarding the positive relation between GINDEX and credit ratings, for the one year of their study (2003) if we use their coarser industry classification - a dummy variable set equal to one if the firm is classified as a utility or is in the financial services industry. However, when we extend the data from 2001 to 2007, and use the FamaFrench 48 industry classifications, we find that this relation is insignificant. ${ }^{27}$

Model 2 replaces the financial variables in Model 1 with the firms' governance variables, including the measure of earnings quality as developed by Ecker et al. and discussed in the previous section. The purpose here is twofold: first, to examine the relative importance of governance metrics relative to

\footnotetext{
${ }^{26}$ See Table 2 for the variables included in the GINDEX index.

${ }^{27}$ In our analysis we found a number of relations that hold in some periods (years) but not in others. Thus, researchers are to be cautioned about drawing general conclusions based on relatively few years of data.
} 
financial metrics in explaining credit ratings and second, to identify the governance variables that are significantly related to credit ratings.

The results reported in Table 3 indicate that credit ratings are in fact significantly positively related to earnings quality, which suggests that S\&P credit ratings do reflect the quality of a firm's reported earnings. Indeed, looking across the row of the table, this variable is highly significant in all specifications of the model. Higher earnings quality is associated with higher credit ratings.

Two ownership-structure variables are negatively related to a firm's credit rating: the number of stockholders who hold 5\% or more of the firm's outstanding stock and the percentage of shares held by insiders. One interpretation of the negative relation between ratings and the number of block holders stems from the fact that creditors may be wary of potential takeovers, since bondholders of target firms often suffer significant capital losses ${ }^{28}$ and a greater number of block holders increases the likelihood of a takeover bid. ${ }^{29}$ Alternatively, a large number of block holders suggests that management would be more inclined to side with shareholders regarding any conflict of interest with bondholders. Finally, it is possible that large block holders derive certain "private benefits from control" that come at the expense of the firm's other financial stakeholders - stockholders and creditors alike. ${ }^{30}$

The negative relation between credit ratings and the percentage of shares held by insiders is a curious result. One interpretation is that the more shares held by insiders the more sympathetic the management would be to its shareholders in any dispute involving the firm's creditors. It is also the case that insider ownership might increase the potential for self dealing on the part of the firm's management.

The results of Model 2 regarding executive characteristics indicate that credit ratings are lower the longer the tenure of a firm's CEO. This result is understandable if tenure is a proxy for "entrenchment." Managers who are immune from the pressures exerted by the forces in the market for corporate control, both internal and external, do not have the same incentives to maximize the value of the firm's securities and, as a result, the firm's credit rating suffers. An alternative explanation is that long-tenured CEOs may be the result of a family-controlled corporation, in which the operating strategy is not necessarily to maximize the value of the firm's outstanding securities. Interestingly, we find a negative relation between

\footnotetext{
${ }^{28}$ See, e.g, Bradley, Desia and Kim (1988)

${ }^{29}$ See Cremers, Martijn, and Nair (2005) who find that block holders and takeover vulnerability, as proxied by anti-takeover devices are complementary in increasing the likelihood of a firm being taken over.

${ }^{30}$ See e.g. Barclay and Holderness (1989).
} 
CEO salaries and credit ratings, although the statistical significance diminishes once accounting variables are included in the model.

A number of variables relating to the structure of the board are significantly related to credit ratings. Board size is positively related to credit ratings, and this is true even when the size of the firm and its capital structure are held constant. (See Models 3-5). ${ }^{31}$ The data also indicate that the greater the percentage of independent directors on the board and the greater the percentage of directors with more than 15 years tenure with the firm, the higher the firm's credit rating. These latter two results suggest that stable, outside directors are beneficial to a firm's credit quality. ${ }^{32}$

Unlike the results regarding managers, credit ratings are positively related to the tenure of the board of directors, as measured by the percentage of board members who have served the firm for 15 years or more. Thus, credit ratings are higher the longer the tenure of the firm's board members and the shorter the tenure of the firm's CEO. This suggests that from a credit perspective, managers and directors are not viewed through the same lens. Another example of this is the fact that the greater the percentage of shares held by CEOs, the lower the credit rating, although this relation is not statistically significant. However, credit ratings are significantly negatively related to the percentage of directors who hold zero of the firm's equity. In sum, credit ratings are positively related to the length of service and the number of shares held by directors, but are negatively related to the tenure and holdings of CEOs. While on the surface this result is counterintuitive, the explanation from a credit perspective might also be linked to the potential for short term "equity capture" - for example, when a CEO or short term activist shareholders with a large equity stake may favor disproportionately or unfairly the interests of short term shareholders relative to creditors. More stable boards, on the other hand, may be more conservative in their strategies in a way that might be supportive of longer term interests of creditors and possibly other nonfinancial stakeholders. Finally, the results of Model 2 are consistent with those reported under Model 1 regarding the fact that there is no significant relation between credit ratings and GINDEX.

Model 3 contains both financial and governance variables. The results show that the addition of the governance variables does not diminish the significance of the financial variables. All of the

\footnotetext{
${ }^{31}$ This evidence is consistent with Anderson, Mansi, and Reeb (2004) and Larcker, Richardson, Tuna (2004).

${ }^{32}$ See e.g., Bhagat \& Black (2002) regarding the effectiveness of outside v. inside directors. The result with regard to outside directors is consistent with that reported in Bhojraj and Sengupta (2003).
} 
coefficients of the financial variables have the expected signs and all are highly significant. Moreover almost all of the governance variables retain their signs and significance levels when the financial data are added to the model. This implies that there is information in the governance variables regarding credit ratings that is not reflected in the firm's financial data and vice versa.

Both the number of $5 \%$ block holders and the number of shares held by insiders continue to be negatively related to credit ratings even after the accounting variables are added to the model. Again, we conjecture that these results are due to the potential conflict between controlling stockholders and creditors. As in Model 2, the tenure of the management is negatively related to credit ratings, while credit ratings and the tenure of the board of directors are positively related. Again, as in Model 2, the results from Model 3 suggest that the number of shares held by the CEO is negatively related to credit ratings (although the relation is not statistically significant), whereas the percentage of the board that holds zero equity in the firm is negatively related to credit ratings. Board size continues to be positively related to credit ratings. Finally, note that the GINDEX is not related to credit ratings in this specification.

The results of Model 3 suggest that credit ratings reflect differences between managers and directors. The results suggest that credit ratings are higher the greater the percentage of the firm's directors with 15 or more years of service and the lower the percentage of directors who hold none of the firm's stock. In contrast, ratings are lower the greater the tenure of the firm's management and the more shares held by the firm's management.

In order to better examine the conflicting results regarding officers and directors, we combine a subset of the factors of GINDEX into two separate indices. The first is the "entrenchment index" (EINDEX) defined by Bebchuk et al. and is calculated as the sum of six indicator variables whose value is one if the indicated characteristic is present and zero otherwise. The variables include: golden parachutes, limits to amend bylaws, limits to amend charter, poison pills, staggered boards and supermajority requirements. The second index we construct, BINDEX, is designed to capture the stability and discretion of the board in overseeing the affairs of the company. Specifically, BINDEX is equal to the sum of six indicator variables, each of which is equal to 1 if the stated condition is met and zero otherwise. The indicator variables are (1) the presence of charter amendments that limit the director's liability; (2) whether the directors are indemnified by the firm's charter or bylaws; (3) whether the directors are indemnified by 
contracts with the firm, and (4) whether the firm has a classified (staggered) board. The higher the value of the index, the greater is the stability and potential discretion of the board.

Note that the two indexes that we employ draw a distinction between directors and executive management. The vast majority of the literature in this area ignores any distinction between the two. From a credit perspective the distinction might reflect a tendency of executive management on the one hand to be "captured" by short term shareholder interests, and the resulting need for strong board directors on the other hand to temper undue equity bias - in the spirit of exercising long term fiduciary stewardship for the firm as a whole (including creditors and other stakeholders).

The careful reader will have noticed that the presence of a staggered board is included in both EINDEX and BINDEX. A staggered or classified board gives the directors a certain degree of stability of tenure, since each director comes up for election typically once ever 3 years. However, a number of legal scholars have argued that a staggered board is perhaps the most effective entrenchment device available to management. ${ }^{33}$ Since a staggered (classified) board can have these two opposing effects, we include it in both indexes. $^{34}$

The first thing to note in Model 4 is that the addition of these two independent variables (BINDEX and EINDEX) does not affect any of the signs of the independent variables in Model 3 nor their statistical significance. BINDEX, our index of board stability/discretion, is positively related to credit ratings. In contrast, EINDEX is negatively related to credit ratings. Thus, it appears that credit ratings positively reflect stable and unencumbered boards, but not entrenched management. The opposite signs on these two variables suggest that the positive relation between the GINDEX and credit scores that has been documented in the literature may not be due to anti-takeover devices but rather board stability and discretion. To examine this issue further, we generate an interaction term equal to the product of EINDEX and a binary variable, BIG, that equals 1 if the firm's debt is below investment grade and zero otherwise.

The results of Model 5 demonstrate that the addition of this interaction variable does not affect either the signs or the statistical significance of most of the independent variables of Model 3. In addition, BINDEX remains significantly positively related to credit ratings. However, adding the interaction term "flips" the sign on EINDEX, which suggests that there is a differential relation between management

\footnotetext{
${ }^{33}$ Bebchuk, Coates and Subramanian (2002), Bebchuk and Cohen (2005), and Faleye (2007).

${ }^{34}$ The simple correlation between EINDEX and BINDEX is 0.33.
} 
entrenchment and credit ratings, depending on the level of the firm's credit rating. For firms that have investment grade credit ratings, the higher the management entrenchment the higher the rating, whereas for firms with below investment grade debt, the higher the management entrenchment the lower the rating.

The opposite signs on EINDEX (+) and the interaction term EINDEX * BIG (-) suggest that for firms with below investment grade debt, anti-takeover (entrenchment) devices are detrimental to creditors because if there were to be a merger, there is a chance that the credit quality of the acquirer may increase the credit quality of the target's debt - the so-called "co-insurance” effect. Thus, bondholders who hold less than investment grade debt may be hurt by anti-takeover devices to the extent they both entrench management and thwart potentially positive takeover related activity. In contrast, bondholders who hold investment grade debt tend to benefit from anti-takeover devices because in many cases, the financial impact of a takeover would have more negative than positive implications for investment grade firms. ${ }^{35}$

Finally, the results for Model 5 demonstrate that credit ratings are lower for firms incorporated in Delaware. This result is consistent with those of Francis, Hasan, John, and Waisman (2006), who document greater when-issued spreads for bonds issued by Delaware corporations. They attribute the higher cost of debt for firms incorporated in Delaware to the potential of a takeover, as Delaware has few anti-takeover statutes. ${ }^{36}$ However, the fact that we account for the probability of a takeover with other independent variables, namely EINDEX, suggests that the lower ratings for Delaware firms might be due to the more general conflict of interests between bondholders and stockholders ${ }^{37}$ and not specifically the probability of a takeover.

\section{B. Financial Condition, Credit Ratings, Governance Attributes and Bond Spreads}

In this section we examine the extent to which bond spreads are related to governance factors, after controlling for the issuing firm's financial profile, sector, and credit rating. As presented in the

\footnotetext{
${ }^{35}$ We performed additional robustness checks by separating the sample into those firms with investment-grade ratings and those with speculative-grade ratings. We ran regressions separately on these two sub-samples. We found that for the sample with the investmentgrade firms, the coefficient on the EINDEX is positive, but for the sample with the speculative-grade firms, it is negative. This is consistent with our result regarding the interaction term in Model 5.

${ }^{36}$ Among the major state anti-takeover statutes, Delaware only has a business combination statute that can be circumvented in a number of ways.

${ }^{37}$ See note 41 infra for references regarding Delaware's pro-stockholder (anti-creditor) position regarding the fiduciary duties of corporate directors.
} 
previous section, governance factors are related to credit ratings after taking into consideration the effects of the firm's financial condition. Here we are assessing the extent to which credit ratings affect bond prices relative to governance-related factors. As presented in the previous section, governance factors are related to credit ratings even after taking into consideration the effects of the firm’s financial condition.

Our sample of bond spreads is a proprietary database provided by S\&P and consists of annual "snapshots" of all traded domestic corporate bonds that are rated by S\&P. Each snapshot is taken at the end of March trading date for each of the years 2002-2007. All of the bonds in the sample are senior, unsecured obligations. Most of the firms in the sample have more than one bond outstanding. There are 7,456 bond-year observations for 1,734 firm-year observations with an average of 4.3 bonds per firm. ${ }^{38}$

Our results regarding the relation between bond spreads, credit ratings and governance variables are presented in Table 5. The dependent variable in these regressions is the spread (difference) between the bond's yield-to-maturity and the yield-to-maturity of a U.S. Treasury Bond with the closest maturity. The first thing to note is that bond spreads are significantly related to bond ratings. All of the rating categories are highly significant and, except for the two highest ratings categories, ${ }^{39}$ the coefficients are monotonically related to bond spreads - the higher the credit rating, the lower the spread. Moreover, the ratings are highly significant in the full specification of the statistical model - Model 5.

In Model 2 we examine the relation between bond spreads, financial condition and governance factors, without regard to the firm's credit rating. We find no relation between spreads and the years to maturity (YTM) or the issue size. Consistent with our finding of a positive relation between earnings quality and credit ratings, here we find a negative relation between earnings quality and spreads. Higher quality earnings reduce the spread between the required yield on the firm's debt and the yield to U.S. treasuries. Note that this variable is highly significant in all specifications of the statistical model. Particularly noteworthy is the fact that Earnings Quality is highly significant in Model 5, which includes ratings. This suggests that bond traders assign a greater importance to the firm's earnings quality than is reflected in the bond's rating.

\footnotetext{
${ }^{38}$ We also perform our tests on a subset of the sample that includes only the largest bond issue of each firm. Our results for this subsample are not materially different than those for the entire sample, and are therefore not reported.

${ }^{39}$ The estimated coefficients for these two categories are not statistically different from each other.
} 
By and large, the coefficients on most of the financial variables have the opposite sign to those in the ratings regressions reported in Tables 3 and 4, which represents the logical relation between credit ratings and the credit risk premium. Thus bond spreads are greater (1) if the firm had negative earnings in the prior two years; (2) the greater leverage; (3) the lower ROA; (4) if the firm has subordinated debt; and (5) the lower the firm's capital intensity. Note that leverage and the return on assets become insignificant when ratings are included in the model - Model 5. Presumably this information is already reflected in the bonds' ratings.

Curiously, size is positively related to spreads, but only significantly so in the full model. Recall that we have documented a positive relation between size and ratings - larger firms typically have higher credit ratings, which should translate into lower, not higher spreads. However, the fact that the relation is statistically significant only in the model containing ratings suggests that bond traders assign less importance to firm size than is reflected in a bond's rating. In other words, given a bond's rating, traders may apply a discount for size, which may be at odds with how ratings reflect the beneficial effects of firm size to bondholders.

The results of Models 2 - 5 indicate that the number of shareholders holding blocks of $5 \%$ or more of the firm's shares is positively related to bond spreads, which is consistent with the result we obtained in the ratings regressions. Again, concentrated ownership creates the possibility that the firm will be run in the interests of its shareholders, or the block holders themselves, at the expense of the firm's creditors -- should a conflict between the interests of the two groups arise.

The annual base pay of a firm's CEO is negatively related to the spread on its bonds in all specifications of the model. Indeed, the significance of the relation strengthens with the inclusion of additional independent variables. Recall that we found no relation between CEO base pay and credit score. Thus, it appears that bond traders may be more concerned about the base pay of the firm's CEO than is reflected in the firm's credit rating.

A surprising result is that the percentage of directors holding none of a firm's stock is negatively related to bond spreads. This is surprising because we found that this variable is negatively related to ratings as well - a potentially conflicting set of results. As reported in Tables 3 and 4, the greater the percentage of zero-shareholding directors, the lower is the firm's credit rating, and hence the higher should 
be the spread on the firm's bonds. Moreover, this variable remains significantly positive even after we add the firm's credit rating to the statistical model (Model 5). Thus, even though credit ratings are negatively related to the percentage of zero-shareholding directors, the spread between the yields on corporate and U.S. Treasury bonds are also lower the greater the percentage of zero-shareholding directors. This suggests that creditors may have greater concern about possible "equity capture" of board directors that might come with greater equity ownership by directors, whereas the credit rating appears to reflect more the positive incentive that equity ownership offers to engage its directors to perform diligently.

The results of Model 2 indicate that the GINDEX is unrelated to spreads, which contrasts with the findings in Klock, Mansi, and Maxwell (2005), who document a negative and significant relation between GINDEX and bond spreads for the period between 1990 and 2000.

The results of Model 3 show that BINDEX (board stability/discretion) is negatively related to spreads, which is consistent with what we found regarding the relation of this variable to credit ratings. EINDEX (anti-takeover mechanisms) is positively related to spreads; however unlike in the case of credit ratings EINDEX does not show significant differentiation depending on whether or not the underlying debt is investment grade or speculative grade. Finally, consistent with our ratings' results, we find that EINDEX is associated with greater spreads for below investment grade bonds. ${ }^{40}$

The last variable we entertain in the spread regressions is an indicator variable regarding Delaware incorporations. Consistent with the negative relation between this variable and ratings, the results show that the variable is significantly positively related to spreads in all specifications of the statistical model. Apparently, Delaware firms pay a penalty in both ratings and spreads when they issue corporate bonds. This is consistent with a recent Delaware decision that states emphatically that in Delaware, the fiduciary duties of officers and directors run exclusively to the corporation and its stockholders. Officers and directors owe only contractual duties to creditors. ${ }^{41}$ This evidence is also consistent with the findings in Francis, Hasan, John, and Waisman (2006) and Chava, Dierker, Livdan, and Purnanandam (2007).

\footnotetext{
${ }^{40}$ This result suggests that there may be different relations between investment and speculative issues more generally. We leave this possibility to future research.

${ }^{41}$ No. Am. Catholic Educational Programming v. Rob Gheewalla et al.,Supreme Court of Delaware, 521 A.2 92 (Del. May, 2007) ("It is well established (in Delaware) that the directors owe their fiduciary obligations to the corporation and its shareholders. While shareholders rely on directors acting as fiduciaries to protect their interests, creditors are afforded protection (only) through contractual agreements, fraud and fraudulent conveyance law, implied covenants of good faith and fair dealing, bankruptcy law, general commercial law and other sources of creditor rights.”).
} 
There are two important points regarding the results reported in Table 4, especially Model 5. The first point is that while credit ratings are assigned by rating agencies, the price and hence the yield on corporate debt is determined by the market. In other words, credit ratings are determined by firm-specific characteristics, whereas the market prices (yields) of corporate debt, or any financial instrument for that matter, are determined by the interaction of supply and demand for credit. Spreads can be thought of as a description of market equilibrium, which involves both supply and demand factors in the financial markets, whereas credit ratings focus exclusively on the qualities of the rated issuer.

The second note of caution regarding the interpretation of the results reported in Model 5 of Table 4 is that the coefficients on the independent variables are conditioned on the firm's credit rating and, as we have seen previously, credit ratings are statistically related to a number of financial and governance variables. Thus, coefficients are to be interpreted conditionally.

\section{Conclusion}

This paper has identified several statistically significant relations between corporate governance factors, and credit ratings and bond spreads for some recent panel samples. Among the numerous results of our panel study, one of the most interesting findings is that the presence of anti-takeover mechanisms is more negatively related to credit ratings and more positively related to bond spreads, when the firm's credit rating is speculative (BB+ and below) than when it is investment grade (BBB- and above). In the case of credit ratings, such presence of anti-takeover mechanisms is related to lower credit ratings for firms with speculative grade credit ratings, and higher credit ratings for firms with investment grade ratings. This is a new finding, and one that has an obvious interpretation. Bondholders of investment grade debt often have more to lose than gain when an investment grade company is the target of a takeover event, particularly if the takeover increases financial leverage. However for companies with speculative grade ratings, antitakeover provisions can be viewed as inhibiting potentially positive takeover events that could remove entrenched management or result in the company becoming part of an operationally and financially stronger organization.

Other important findings of this paper relate to the relations we identified between certain director characteristics, credit ratings and bond spreads. We identify a cluster of attributes relating to board tenure, 
director liability indemnification and classified board structures, which are related to higher credit ratings and lower bond spreads, after controlling for financial variables and industrial sector. We believe this cluster of attributes reflects the relative stability of the board. Our findings suggest that boards with greater stability, financial exposure and protection from liability may be more conservative and better positioned to exercise discretion relative to executive management in ways that are supportive of creditors' interests. Boards with greater stability arguably have a greater ability to take a long term perspective and, in a fiduciary context, to take into consideration the broader interests of the firm as a whole, including creditors and potentially other stakeholders.

This paper builds on the existing literature concerning the relations between governance metrics, credit risk and financial performance. In particular we have replicated the findings of Ashbaugh, Collins and LaFond (2006, ACL). We find that the GINDEX (ACL's shareholder rights index) is not statistically significant in a broader time series beyond their one-year analysis. The more focused entrenchment index (EINDEX) developed by Bebchuck, Cohen and Ferrill (2004) is more resilient, and is statistically significant for both credit ratings and bond spreads over the period 2001-2007 and 2002-2007, respectively.

While we have identified a number of statistically significant relations between governance attributes and credit risk, we are not asserting causality. However we do believe the relations we have identified can be logically explained and have a foundation in both theory and in professional practice. Our study has several distinctive attributes, including the range of governance variables employed, the use of seasoned bond spreads rather than when-issued bond spreads as in most of the literature and the seven-year time series we were able to construct. 
Table 1

Variable Definitions, Type and Sources

Dependent Variables

RATE

SPREAD

\section{Definitions and Calculations}

Type $^{1}$

Data Source $^{2}$

Grouped 7 categories out of S\&P bond ratings. Specifically, rate $=1$ if Rating $<=\mathrm{CCC}+$; rate $=2$ if $\mathrm{CCC}+<$ Rating $<=\mathrm{B}+$; rate $=3$ if $\mathrm{B}+<$ Rating $<=\mathrm{BB}+$; rate $=4$ if

$\mathrm{BB}+<$ Rating $<=\mathrm{BBB}+$; rate $=5$ if $\mathrm{BBB}+<$ Rating $<=\mathrm{A}+$; rate $=6$ if $\mathrm{A}+<$ Rating $<=\mathrm{AA}+$; rate $=7$ if Rating $>A A+$. (data280)

The difference between bond yield and treasury yield with same maturity

\section{Financial / Firm Variables}

LEV
ROA
LOSS
INT_COV
SIZE
SUBORD
CAP_INTEN
R\&D

\section{Issue Characteristics}

Leverage ( =(data9+data34)/data6)

Return on asset (=data18/data6)

Equals 1 if ROA is negative in current and prior fiscal year

Interest coverage (= data13/(data15 or data339))

Log of total assets (log(data6))

Equals 1 if the firm has subordinated debt (data80)

Capital intensity (=data7/data6)

Annual Research \& Development expenses divided by total asset

$\begin{array}{ll}\text { C } & \text { COMPUSTAT } \\ \text { C } & \text { COMPUSTAT } \\ \text { D } & \text { COMPUSTAT } \\ \text { C } & \text { COMPUSTAT } \\ \text { C } & \text { COMPUSTAT } \\ \text { D } & \text { COMPUSTAT } \\ \text { C } & \text { COMPUSTAT } \\ \text { C } & \text { COMPUSTAT }\end{array}$

ISSUESIZE YTM
Face amount of bond issue scaled by 10,000,000,000

Years to maturity $\begin{array}{ll}\text { C } & \text { S\&P Snaphot } \\ \text { C } & \text { S\&P Snapshot }\end{array}$

\footnotetext{
${ }^{1} \mathrm{C}$ denotes continuous variable; $\mathrm{D}$ denotes a binary variable equal to 1 if the specified condition is met and zero otherwise.

${ }^{2}$ TCL is The Corporate Library; CRSP is the Center for the Study of Security Prices, S\&P Snapshot is a proprietary database of S\&P containing coupons, prices and maturities of traded corporate bonds; SDC is the Securities Data Corporation division of Thompson Financial; IRRC is the Investor Responsibility Research Center.
} 
Ownership Structure

NUM_BLK5

PER_INSIDE

PER_INST number of at least $5 \%$ blockholders

Percentage of shares held by top management and directors

percentage of institutional holding
C
$\mathrm{CDA} /$ Spectrum

TCL

$\mathrm{CDA} /$ Spectrum

Transparency

The loadings on the accrual quality (AQ) factor as augmented from the Fama-French three-factor model, where AQ is defined as the standard deviation of the residuals from the regressions of the change in working capital on past, current, and future cash flow

EARNINGS QUALITY... from operations (Ecker, Francis, Kim, Olsson, and Schipper (2006)).

\section{DELAWARE}

Equals 1 if the firm is incorporated in Delaware
Frank Ecker of Duke University

D

COMPUSTAT

\section{Board Structure}

BOARD_SIZE
DIRIND
DIRINDC
DIRLIAB
PER_15_TNUR
PER_4BOARDS
PER_70_AGE
PER_EQTY_ZERO
PER_MEET
PER_OUT

Board size

Director Indemnification

Director Indemnification Contracts

Charter Amendments That Limit the Director's Liability

Percentage of directors over 15 years' tenure

Percentage of directors who sit on at least four other corporate boards

Percentage of directors over 70

Percentage of directors with zero equity

Percentage of directors who fail to attend at least $80 \%$ of board meetings

Percentage of independent directors

$\begin{array}{lc}\text { C } & \text { TCL } \\ \mathbf{D} & \text { IRRC } \\ \mathbf{D} & \text { IRRC } \\ \mathbf{D} & \text { IRRC } \\ \mathbf{C} & \text { TCL } \\ \mathbf{C} & \text { TCL } \\ \mathbf{C} & \text { TCL } \\ \mathbf{C} & \text { TCL } \\ \mathbf{C} & \text { TCL } \\ \mathbf{C} & \text { TCL }\end{array}$




\section{Executive Compensation and Turnover}

CEO_BASE

CEO_BONUS

CEO_SHARES

CEO TENURE

CEO_INCEN
Annual base salary of CEO as a percentage of total compensation

Annual bonus of CEO as a percentage of total compensation

CEO Share holding as a percentage of total shares outstanding

CEO tenure

Proportion of incentive part of CEO compensation
C

C

C

C
TCL

TCL

TCL

TCL

COMPUSTAT EXECUCOMP 
Table 2

Components of Governance Indexes

\begin{tabular}{lccc}
\hline & GINDEX & EINDEX $^{\mathbf{2}}$ & BINDEX $^{\mathbf{3}}$ \\
\hline Golden Parachutes & & & \\
Limits to Amend Bylaws & $\sqrt{ }$ & $\sqrt{ }$ & \\
Limits to Amend Charter & $\sqrt{ }$ & $\sqrt{ }$ & \\
Poison Pills & $\sqrt{ }$ & $\sqrt{ }$ & \\
Staggered Board & $\sqrt{ }$ & $\sqrt{ }$ \\
Supermajority & $\sqrt{ }$ & $\sqrt{ }$ \\
& & \\
Anti-green Mail & $\sqrt{ }$ & \\
Blank Check & $\sqrt{ }$ & \\
Business Combination Law & $\sqrt{ }$ & \\
Cash Out Law & $\sqrt{ }$ & \\
Compensation Plans & $\sqrt{ }$ & \\
Director Duties & $\sqrt{ }$ & \\
Director Indemnification & $\sqrt{ }$ & \\
Director Indemnification Contracts & $\sqrt{ }$ & \\
Director Liability & $\sqrt{ }$ & \\
Fair Price & $\sqrt{ }$ & \\
Limits to Special Meetings & $\sqrt{ }$ & \\
Limits to Written Consent & $\sqrt{ }$ & \\
No Cumulative Vote & $\sqrt{ }$ & \\
No Secret Ballot & $\sqrt{ }$ & \\
Pension Parachutes & $\sqrt{ }$ & \\
Severance Agreements & $\sqrt{ }$ & \\
Silver Parachutes & & \\
Unequal Vote & & \\
& &
\end{tabular}

\footnotetext{
1 "Governance Index" constructed by Gompers, Ishi and Metrick in "Corporate Governance and Equity Prices," (2003)

2"Entrenchment Index" constructed by Bebchuk, Cohen and Ferrell in "What Matters in Corporate Governance?” (2005)

${ }^{3}$ Board Discretion Index
} 


\section{Table 3}

\section{Ordered-Logistic Regression Results for Credit Ratings}

All models include Finance \& Utility companies. Samples cover the period 2001-2007. The dependent variable is firm's credit rating, defined as the grouped seven categories from S\&P's ratings. ${ }^{1}$ All models include Fama-French 48-industry and year dummy variables. Standard errors are adjusted for heteroscedasticity and clustered by firms. t-statistics are reported in brackets.

* significant at $10 \%$; ** significant at $5 \%$;*** significant at $1 \%$

\begin{tabular}{llllll}
\hline Independent Variables & Model 1 & Model 2 & Model 3 & Model 4 & Model 5 \\
\hline
\end{tabular}

\section{Financial Data}

\begin{tabular}{|c|c|c|c|c|c|}
\hline SIZE & $\begin{array}{l}1.234^{* * *} \\
{[15.193]}\end{array}$ & & $\begin{array}{l}1.122 * * * \\
{[12.255]}\end{array}$ & $\begin{array}{l}1.074 * * * \\
{[11.667]}\end{array}$ & $\begin{array}{c}0.976 * * * \\
{[9.928]}\end{array}$ \\
\hline LEV & $\begin{array}{c}-2.515^{* * *} \\
{[4.262]}\end{array}$ & & $\begin{array}{c}-2.142 * * * \\
{[3.598]}\end{array}$ & $\begin{array}{c}-2.235^{* * *} \\
{[3.810]}\end{array}$ & $\begin{array}{c}-1.601^{* *} \\
{[2.499]}\end{array}$ \\
\hline ROA & $\begin{array}{c}9.273^{* * *} \\
{[6.375]}\end{array}$ & & $\begin{array}{c}8.273 * * * \\
{[5.464]}\end{array}$ & $\begin{array}{c}8.158 * * * \\
{[5.379]}\end{array}$ & $\begin{array}{c}7.463 * * * \\
{[5.020]}\end{array}$ \\
\hline LOSS & $\begin{array}{c}-1.763 * * * \\
{[6.750]}\end{array}$ & & $\begin{array}{c}-1.589 * * * \\
{[5.996]}\end{array}$ & $\begin{array}{c}-1.589 * * * \\
{[5.965]}\end{array}$ & $\begin{array}{c}-1.304 * * * \\
{[4.225]}\end{array}$ \\
\hline SUBORD & $\begin{array}{c}-0.983^{* * *} \\
{[6.331]}\end{array}$ & & $\begin{array}{c}-0.911^{* * *} \\
{[5.686]}\end{array}$ & $\begin{array}{c}-0.837^{* * *} \\
{[5.209]}\end{array}$ & $\begin{array}{c}-0.297 \\
{[1.593]}\end{array}$ \\
\hline INT_COV & $\begin{array}{c}0.006 * * \\
{[2.067]}\end{array}$ & & $\begin{array}{c}0.006 * * \\
{[2.300]}\end{array}$ & $\begin{array}{c}0.006^{* *} \\
{[2.094]}\end{array}$ & $\begin{array}{c}0.009 * * * \\
{[3.235]}\end{array}$ \\
\hline CAP_INTEN & $\begin{array}{c}0.664 * * * \\
{[2.933]}\end{array}$ & & $\begin{array}{c}0.497 * * \\
{[2.273]}\end{array}$ & $\begin{array}{c}0.485^{*} \\
{[2.097]}\end{array}$ & $\begin{array}{c}0.195 \\
{[0.884]}\end{array}$ \\
\hline lings Qua & & $\begin{array}{c}1.238 * * * \\
{[7.231]}\end{array}$ & $\begin{array}{c}1.064 * * * \\
{[5.688]}\end{array}$ & $\begin{array}{c}1.056 * * * \\
{[5.592]}\end{array}$ & $\begin{array}{c}1.193 * * * \\
{[5.760]}\end{array}$ \\
\hline
\end{tabular}

\section{Ownership Structure}

$\begin{array}{lcccc}\text { NUM_BLK5 } & -0.368^{* * *} & -0.162^{* * *} & -0.165^{* * *} & -0.142 * * * \\ \text { PER_INSIDE } & {[7.596]} & {[3.370]} & {[3.395]} & {[2.857]} \\ & -1.686^{* * *} & -1.085^{* *} & -1.033^{* *} & -1.205^{* *} \\ \text { PER_INST } & {[4.491]} & {[2.502]} & {[2.412]} & {[2.532]} \\ & 0.234 & -0.352 & -0.175 & -0.696 \\ & {[0.394]} & {[0.580]} & {[0.292]} & {[1.075]}\end{array}$

${ }^{1}$ Specifically, Rate $=1$ if Rating $<=$ CCC + ; Rate $=2$ if CCC $+<$ Rating $<=B+$; Rate $=3$ if $\mathrm{B}+<$ Rating $<=$ BB + ; Rate $=4$ if $\mathrm{BB}+<$ Rating $<=\mathrm{BBB}+$; Rate $=5$ if $\mathrm{BBB}+<$ Rating $<=\mathrm{A}+$; Rate $=6$ if $\mathrm{A}+<$ Rating $<=\mathrm{AA}+$; Rate $=7$ if Rating $>\mathrm{AA}+$. (COMPUSTAT data280). 
\begin{tabular}{llllll}
\hline Independent Variables & Model 1 & Model 2 & Model 3 & Model 4 & Model 5 \\
\hline
\end{tabular}

\section{Executive Data}

$\begin{array}{lcccc}\text { CEO_TENURE } & -0.022^{* *} & -0.018^{*} & -0.016^{*} & -0.015 \\ \text { CEO_BASE } & {[2.372]} & {[1.960]} & {[1.734]} & {[1.334]} \\ & -1.661^{* * *} & -0.129 & -0.192 & 0.068 \\ \text { CEO_BONUS } & {[7.416]} & {[0.547]} & {[0.815]} & {[0.258]} \\ & 0.061 & -0.282 & -0.331 & -0.640^{* *} \\ \text { CEO_SHARES } & {[0.252]} & {[1.177]} & {[1.384]} & {[2.465]} \\ & -2.541 & -1.761 & -2.106 & -2.781 \\ & {[0.252]} & {[1.177]} & {[1.384]} & {[2.465]}\end{array}$

\section{Board Structure}

$\begin{array}{lcccc}\text { BOARD_SIZE } & 0.299^{* * *} & 0.122^{* * *} & 0.120^{* * *} & 0.129^{* * *} \\ \text { PER_15_TNUR } & {[8.837]} & {[3.328]} & {[3.262]} & {[3.495]} \\ & 2.073^{* * *} & 2.060^{* * *} & 1.643^{* * *} & 1.383^{* * *} \\ \text { PER_EQTY_ZERO } & {[4.717]} & {[4.608]} & {[3.421]} & {[2.682]} \\ & -1.236^{* * *} & -0.785^{* * *} & -0.729^{* *} & -0.773^{* *} \\ \text { PER_OUT } & {[4.048]} & {[2.654]} & {[2.372]} & {[2.172]} \\ & 0.845^{* *} & 0.609 & 0.619 & 0.362 \\ \text { PER_70_AGE } & {[2.103]} & {[1.473]} & {[1.500]} & {[0.804]} \\ & -0.615 & 0.12 & -0.052 & 0.275 \\ \text { PER_4BOARDS } & {[0.988]} & {[0.177]} & {[0.077]} & {[0.403]} \\ & 1.704^{* * *} & 0.386 & 0.523 & 0.664 \\ \text { PER_MEET } & {[3.468]} & {[0.767]} & {[1.031]} & {[1.245]} \\ & -1.661 * & -0.81 & -0.853 & -0.485 \\ & {[1.650]} & {[0.800]} & {[0.835]} & {[0.482]}\end{array}$

Governance Indexes

$\begin{array}{cccc}\text { GINDEX } & 0.043 & -0.018 & 0.007 \\ & {[1.435]} & {[0.601]} & {[0.235]}\end{array}$

BINDEX

$\begin{array}{cc}0.271^{* * *} & 0.253^{* * *} \\ {[3.568]} & {[3.221]} \\ -0.163^{* * *} & 0.213^{* * *} \\ {[2.579]} & {[2.858]} \\ & -1.469 * * * \\ & {[16.838]} \\ -0.297 * & -0.280^{*} \\ {[1.865]} & {[1.691]}\end{array}$

Delaware Inc.

$\begin{array}{llll}-0.199 & -0.258 & -0.297 * & -0.280 * \\ {[1.320]} & {[1.624]} & {[1.865]} & {[1.691]}\end{array}$

Observations

3209

3209

3209

$3209 \quad 3209$

Pseudo $\mathbf{R}^{2}$

$0.31 \quad 0.21$

0.34

0.35

0.47 


\section{Table 4}

\section{OLS Regression Results for Bond Spreads}

All models include Finance \& Utility companies. Sample covers the period 2002-2007. Dependent variable is spread, defined as the bond's yield-to-maturity minus treasury bond yield with the closest maturity. All models include Fama-French 48 industry and year dummies. Standard errors are adjusted for heteroscedasticity and clustered by firms. t-statistics are reported in brackets.

* significant at $10 \%$; $* *$ significant at $5 \%$; *** significant at $1 \%$

\begin{tabular}{llllll}
\hline Independent Variables & MODEL 1 & MODEL 2 & MODEL 3 & MODEL 4 & MODEL 5 \\
\hline
\end{tabular}

\section{Ratings Categories}

$\begin{array}{lc}\mathbf{C C C}^{+}<\mathbf{R} \leq \mathbf{B}^{+} & -6.104^{* * *} \\ & {[3.441]} \\ \mathbf{B}^{+}<\mathbf{R} \leq \mathbf{B B}{ }^{+} & -7.704^{* * *} \\ & {[5.018]} \\ \mathbf{B B}^{+}<\mathbf{R} \leq \mathbf{B B}^{+} & -9.491^{* * *} \\ & {[5.405]} \\ \mathbf{B B B}^{+}<\mathbf{R} \leq \mathbf{A}^{+} & -9.998^{* * *} \\ & {[5.804]} \\ \mathbf{A}^{+}<\mathbf{R} \leq \mathbf{A A} & -10.438^{+* *} \\ & {[6.079]} \\ \mathbf{A A} & -10.285^{+}<\mathbf{R} \\ & {[5.924]}\end{array}$

$$
\begin{gathered}
-5.099 * * * \\
{[3.767]} \\
-5.610 * * * \\
{[4.872]} \\
-7.362 * * * \\
{[5.367]} \\
-7.805 * * * \\
{[5.787]} \\
-8.137 * * * \\
{[6.147]} \\
-7.777 * * * \\
{[5.780]}
\end{gathered}
$$

\section{Issue Characteristics}

YTM

ISSUESIZE

\section{Earnings Quality}

\section{Financial Data}

SIZE

LOSS

LEV

ROA

INT_COV

SUBORD
0.005
[1.172]
$-0.049$
[0.195]

$$
\begin{gathered}
0.005 \\
{[1.186]} \\
-0.284 \\
{[1.332]}
\end{gathered}
$$

0.004
$[1.073]$
-0.294
$[1.371]$

0.004

[1.023]

$-0.307$

[1.442]

$$
\begin{gathered}
0.004 \\
{[0.972]} \\
-0.295 \\
{[1.449]}
\end{gathered}
$$

$\begin{array}{cccc}-0.756^{* * *} & -0.744^{* * *} & -0.694^{* * *} & -0.505^{* *} \\ {[2.827]} & {[2.858]} & {[2.727]} & {[2.130]}\end{array}$

$-0.756^{* * *}$

[2.858]

$[2.727]$

[2.130]

$\begin{array}{cccc}0.017 & 0.056 & 0.116 & 0.224 * * * \\ {[0.227]} & {[0.733]} & {[1.513]} & {[3.027]} \\ 2.918^{* * *} & 2.876^{* * *} & 2.532^{* * *} & 1.896 * * * \\ {[3.519]} & {[3.591]} & {[3.252]} & {[2.762]} \\ 1.759 * * & 1.878^{* * *} & 1.672 * * * & 0.748 \\ {[2.586]} & {[2.767]} & {[2.614]} & {[1.502]} \\ -2.676 * & -2.641^{*} & -2.13 & -0.217 \\ {[1.840]} & {[1.824]} & {[1.534]} & {[0.115]} \\ -0.009 & -0.01 & -0.007 & -0.005 \\ {[1.335]} & {[1.508]} & {[1.094]} & {[0.915]} \\ -0.196 & -0.279 * & -0.328 * * & -0.306 * * \\ {[1.325]} & {[1.784]} & {[2.186]} & {[2.380]}\end{array}$




\begin{tabular}{cccccc}
\hline Independent Variables & MODEL 1 & MODEL 2 & MODEL 3 & MODEL 4 & MODEL5 \\
\hline CAP_INTEN & & -0.446 & $-0.495^{*}$ & -0.415 & $-0.443^{*}$ \\
& & {$[1.583]$} & {$[1.759]$} & {$[1.529]$} & {$[1.683]$}
\end{tabular}

\section{Ownership Structure}

$\begin{array}{lcccc}\text { NUM_BLK5 } & 0.259^{* * *} & 0.275^{* * *} & 0.266 * * * & 0.227 * * * \\ \text { PER_INSIDE } & {[4.258]} & {[4.434]} & {[4.601]} & {[4.236]} \\ & 0.279 & 0.287 & 0.297 & 0.329 \\ \text { PER_INST } & {[0.681]} & {[0.716]} & {[0.762]} & {[0.955]} \\ & -0.638 & -0.75 & -0.554 & -0.736 \\ & {[1.143]} & {[1.330]} & {[1.043]} & {[1.453]}\end{array}$

\section{Executive Data}

$\begin{array}{lcccc}\text { CEO_BASE } & 1.025^{* *} & 1.058^{* * *} & 1.048^{* * *} & 1.022^{* * *} \\ \text { CEO_BONUS } & {[2.553]} & {[2.740]} & {[2.731]} & {[3.311]} \\ & -0.376 & -0.38 & -0.323 & -0.489^{* *} \\ \text { CEO_SHARES } & {[1.386]} & {[1.433]} & {[1.280]} & {[2.513]} \\ & 1.956 & 2.132 & 1.768 & 1.707 \\ \text { CEO_TENURE } & {[1.048]} & {[1.096]} & {[1.002]} & {[1.204]} \\ & -0.008 & -0.01 & -0.01 & -0.012^{* *} \\ & {[1.189]} & {[1.415]} & {[1.519]} & {[2.092]}\end{array}$

\section{Board Structure}

$\begin{array}{lcccc}\text { BOARD_SIZE } & -0.043 & -0.033 & -0.027 & -0.016 \\ \text { PER_OUT } & {[1.418]} & {[1.148]} & {[0.970]} & {[0.564]} \\ & -0.808 & -0.84 & -0.759 & -0.531 \\ \text { PER_15_TNUR } & {[1.555]} & {[1.620]} & {[1.520]} & {[1.373]} \\ & -0.388 & -0.058 & 0.229 & 0.365 \\ \text { PER_70_AGE } & {[0.748]} & {[0.103]} & {[0.413]} & {[0.824]} \\ & 0.68 & 0.576 & 0.328 & -0.011 \\ \text { PER_4BOARDS } & {[1.140]} & {[0.979]} & {[0.607]} & {[0.026]} \\ & 0.200 & 0.111 & 0.067 & 0.007 \\ \text { PER_MEET } & {[0.415]} & {[0.235]} & {[0.144]} & {[0.017]} \\ & -0.76 & -0.807 & -0.858 & -0.866 \\ \text { PER_EQTY_ZERO } & {[0.780]} & {[0.832]} & {[0.945]} & {[0.942]} \\ & -0.658^{*} & -0.745^{* *} & -0.710^{* *} & -0.767 * * * \\ & {[1.961]} & {[2.224]} & {[2.119]} & {[2.632]}\end{array}$




\begin{tabular}{|c|c|c|c|c|c|}
\hline Independent Variables & MODEL 1 & MODEL 2 & MODEL 3 & MODEL 4 & MODEL 5 \\
\hline \multicolumn{6}{|l|}{ Governance Indexes } \\
\hline GINDEX & & $\begin{array}{c}0.029 \\
{[1.186]}\end{array}$ & & & \\
\hline BINDEX & & & $\begin{array}{c}-0.193 * * * \\
{[2.885]}\end{array}$ & $\begin{array}{c}-0.163^{* * *} \\
{[2.624]}\end{array}$ & $\begin{array}{c}-0.106^{* *} \\
{[2.139]}\end{array}$ \\
\hline EINDEX & & & $\begin{array}{c}0.148^{* * * *} \\
{[2.689]}\end{array}$ & $\begin{array}{c}0.096^{*} \\
{[1.958]}\end{array}$ & $\begin{array}{c}0.139 * * * \\
{[3.294]}\end{array}$ \\
\hline EINDX * BIG & & & & $\begin{array}{c}0.342 * * * \\
{[5.545]}\end{array}$ & $\begin{array}{c}-0.169 \\
{[1.225]}\end{array}$ \\
\hline Delaware Inc. & & $\begin{array}{c}0.253 * \\
{[1.761]}\end{array}$ & $\begin{array}{c}0.307 * * \\
{[2.137]}\end{array}$ & $\begin{array}{c}0.337^{* *} \\
{[2.430]}\end{array}$ & $\begin{array}{c}0.254^{* *} \\
{[2.238]}\end{array}$ \\
\hline Observations & 7456 & 7456 & 7456 & 7456 & 7456 \\
\hline Adjusted $\mathbf{R}^{2}$ & 0.36 & 0.37 & 0.37 & 0.39 & 0.43 \\
\hline
\end{tabular}




\section{References}

Anderson, Ronald, Sattar A. Mansi, and Dvaid M. Reeb, 2004. Board Characteristics, Accounting Report Integrity, and the Cost of Debt. Journal of Accounting and Economics, 37, 315-342.

Ashbaugh-Skaife, H., D. Collins, and R. LaFond, 2006. The Effects of Corporate Governance on Firms' Credit Ratings. Journal of Accounting and Economics, forthcoming.

Barclay, Michael and C. Holderness, 1989. Private Benefits from Control of Public Corporations, Journal of Financial Economics 25, 371-395 (1989).

Bebchuk, Lucian, J.C. Coates IV, and G. Subramanian, 2002. The Powerful Anti-Takeover Force of Staggered Boards: Theory, Evidence and Policy. Stanford Law Review 54, 887-951

Bebchuk, L., A. Cohen, and A. Ferrell, 2004. What Matters in Corporate Governance. Working Paper, Harvard Law School.

Bebchuk, Lucian, and Alma Cohen, 2005. The Costs of Entrenched Boards, Journal of Financial Economics, 78, 409-433

Bertrand, Marianne, and Sendhil Mullainathan, 2003. Enjoying the Quiet Life? Corporate Governance and Managerial Preferences, Journal of Political Economy, 111(5), 1043-1075.

Bhagat, Sanjai and B. Black, 2002. The Non-Correlation Between Board Independence and Long-Term Firm Performance, Journal of Corporation Law 27, 231-274.

Bhojraj, S., and P. Sengupta, 2003. Effects of Corporate Governance on Bond Ratings and Yields: The Role of Institutional Investors and Outside Directors. Journal of Business 76, 455-476.

Billett, Matthew, Tao-Hsien King, and David Mauer, 2004. Bondholder wealth effects in mergers and acquisitions: new evidence from the 1980s and 1990s. Journal of Finance, Vol LIX, No. 1, 107-135.

Bradley, M., A. Desai and E. Han Kim, 1988. Synergistic Gains from Corporate Acquisitions and Their Division Between Target and Acquiring Firms, Journal of Financial Economics_21 (May): 3-40.

Brown, L., and M. Caylor, 2004. Corporate Governance and Firm Performance. Working Paper, Georgia State University.

Chava, Sudheer, Martin Dierker, Dmitry Livdan, and Amiyatosh Purnanandam, 2007. Do Shareholder Rights Affect the Cost of Bank Loans? Working paper, Texas A\&M University.

Cremers, M., K..J. Martijn and V.B. Nair, 2005. Governance Mechanisms and Equity Prices. Journal of Finance Vol. LX, 2859-2894

Cremers, Martijn, Vinay B. Nair, and Chengyang Wei, 2006, Governance Mechanisms and Bond Prices, forthcoming, Review of Financial Studies.

Daines, Robert, 2001, Does Delaware Law Improve Firm Value? Journal of Financial Economics 62, 525558.

Ecker, Frank, Jennifer Francis, Irene Kim, Per M. Olsson, and Katherine Schipper, 2006, A Returns-Based Representation of Earnings Quality. The Accounting Review 81, 749-780

Faleye, Olubunmi, 2007, Classified Boards, Firm Value, and Managerial Entrenchment. Journal of Financial Economics, 83, 501-529. 
Francis, Bill, Iftekhar Hasan, Kose John, and Maya Waisman, 2006, Does Delaware Incorporation Affect the Firm's Cost of Debt Capital? Working paper, Rensselaer Polytechnic Institute.

Gompers, P.A., J.L. Ishii, and A. Metrick, 2003. Corporate Governance and Equity Prices. Quarterly Journal of Economics 118, 107-115.

Klock, Mark, Sattar A. Mansi, and William F. Maxwell, 2005. Does Corporate Governance Matter to Bondholders? Journal of Financial and Quantitative Analysis, vol. 40, no. 4, 693-719

Larcker, David, S. Richardson, and I. Tuna, 2004. Does Corporate Governance Really Matter? Working paper, Wharton School, University of Pennsylvania.

Litov, Lubomir, 2005. Corporate Governance and Financing Policy: New Evidence. Working paper, Washington University.

No. Am. Catholic Educational Programming v. Rob Gheewalla et al.,Supreme Court of Delaware, 521 A. $2^{\text {nd }} 92$ (Del. May, 2007)

Patel, Sandeep A. and George Dallas., 2002. Transparency and Disclosure: Overview of Methodology and Study Results - United States, Available at SSRN:http://ssrn.com/abstract=422800 or DOI:

$10.2139 /$ ssrn. 422800

Petersen, Mitchell, 2007. Estimating Standard Errors in Finance Panel Data Sets: Comparing Approaches. forthcoming, Review of Financial Studies

Standard \& Poor's, 2007. Corporate Governance Scores and Evaluation Criteria, Methodology, and Definitions. Dallas, G. and Kochetygova, J., Standard \& Poor’s RatingsDirect, 7 February 2007.

Subramanian, G. 2004, The Disappearing Delaware Effect. Journal of Law, Economics, \& Organization 20, 32-59. 